\title{
ICT Obstacles and Challenges Faced by English Language Learners During the Coronavirus Outbreak in Jordan
}

\author{
Luqman Rababah \\ School of Arts and Languages, Jadara University \\ Irbid, Jordan \\ E-mail: Rababah80@gmail.com
}

Received: April 24, 2020

Accepted: May 7, 2020

Published: May 17, 2020

doi:10.5296/ijl.v12i3.17048

URL: https://doi.org/10.5296/ijl.v12i3.17048

\begin{abstract}
During the Coronavirus outbreak, the integration of Information and Communication Technology (ICT) has become a necessity, as ICT use in education is a systematic and structured process to improve the quality of education in Jordan. This study aimed at investigating the obstacles and challenges faced by English language students at Jadara University in Jordan while using e-learning programs during the school suspension. To achieve the aim of the study, this qualitative investigation has made use of convenience sample. Twelve students were chosen for a focused group interview where they were requested to answer questions concerning the constraining factors that they experienced while learning through ICT platforms. The findings show that students' responses revealed three themes, namely, lack of effective training, lack of accessibility, and inconsistent teaching styles of instructors. Some of the recommendations suggested are that further research needs to be conducted into the speech acts used by Jordanians on different social networking platforms. Although barriers were significant, this paper recommended additional institutional support for online learning and increased technical and pedagogical training for students.
\end{abstract}

Keywords: Coronavirus outbreak, ICT obstacles, English language learners

\section{Introduction}

There is a relationship between the great scientific revolutions in humanity and educational revolutions that accompany it. One of these revolutions is the Internet which transcends or 
eliminates geographical and regional borders. It plays a prominent and crucial role in our lives, and it has become a new style that has jumped with different knowledge and sciences from limited to comprehensive. It also makes modern communication distinguished. This relationship took a reciprocal pattern, whereby language is the embodiment of how fundamental it is in a person. At the same time, the computer is moving toward simulating some of the human functions and capabilities.

The word technology is derived from the Greek word "Techno" which means desire, skills and knowledge. Today, information technology is represented in the computer and the Internet, and technology has become the most successful means of providing an interactive learning environment to attract students and encourage them to share their opinions and experiences. The strength of the Internet lies in its ability to link people over huge distances and provide a myriad of information sources. This technology increases learning opportunities and extends them beyond the reach of schools, and this process is called e-learning or distance education, which is one of the most important features of learning in the future.

During the Corona outbreak, the integration of Information and Communication Technology (ICT) has become a necessity, as ICT use in education is a systematic and structured process to improve its quality. It helps visualize, implement and evaluate the educational process, and also helps implement modern models of education. Moreover, ICT includes educational materials that regulate work, relationships and the behavior of all participants in this process (Rababah, 2019). The integration of ICT increases students' mastery of educational materials, and allows the repetition of materials that are not sufficiently clear.

\section{Statement of the Problem}

Because of the importance of technology in the teaching and learning process and its role in stabilizing and assisting information to increase achievement, Jadara University has been working since the beginning of the Corona crisis to integrate educational technology in teaching. Jadara University trained its instructors to use technology in education, to fill gaps, and to change the traditional style of teaching, especially under the current circumstances.

Although Jadara University had launched several initiatives, English language students still face obstacles in dealing with the new era. Thus, this difficulty justifies the aims of the current study which focuses on the barriers students face while learning through e-learning platforms. This study is unique because it contributes to the field of ICT integration in EFL settings. This qualitative study may assist policymakers and educators in their evaluation of ICT and EFL initiatives, educational programs, materials, curricula and teaching procedures.

\section{Literature Review}

Constructivism as a Theoretical Foundation for Technology Integration

The theoretical notions of technological integration into classrooms have their foundation on the Theory of Constructivism (Hokanson \& Hooper, 2000; Doolittle \& Hicks, 2003). Constructivism basically stems from the theories of Piaget and Vygotsky and provides a 
distinct explanation of knowledge and learning. On the basis of Piaget and Vygotsky's theories, a summarized explanation of the actual nature of learning was provided by (Fosnot, 2013) in which he stated that:

From this perspective, learning is considered as a self-regulatory process of tackling conflicts between the present personal world models and the discrepant current insights, developing new representations and models of reality as an individual meaning-making attempt with culturally developed tools and symbols, and negotiating the meaning with the help of cooperative social activities, debate and discussions (p. 20).

According to the above explanation, present thinkers of cognition who stress the social aspects of learning are largely motivated by Vygotsky's contribution. Vygotsky's work is unique in that it differs from other cognitive contributions like those made by Gagne and Piaget who concentrated on the cognitive structuring of individuals. Instead, Vygotsky deemed cognitive development as being based on culture and society. Specifically, his theory is based on two primary assumptions (Gredler, 1992). The first is that the signs and symbols created by a specific culture impact the intellectual processes of the members of that society. The second is that social interaction with knowledgeable members has a key role in the cognitive development of the individual.

Vygotsky (1978) contended that the transformation of primitive mental functions like involuntary attention and simple memory, into complex mental functions like conceptual thinking, calls for two distinct but interconnected processes. The first process is mastery over the external thinking means (e.g., language, counting and writing that constitutes the general law of genetic development). The second is learning how to use symbols in hopes of mastering and regulating individual thinking (natural history of the sign).

Specifically, according to the general law of genetic development, every function in the cultural development of the child shows up twice: the first time on the social level and the second time on the individual level. The former arises among people and is known as inter-psychological, while the latter occurs inside the child and is known as intra-psychological.

Stated differently, the development of the entire mental function is initiated in the social interactions of individuals where that function increasingly obtains meaning and, which the individual eventually internalizes. The second principle concerns the way in which the fundamental mental functions shift towards complex functions, and this shift is premised on the signification that it is a psychological tool. According to (Vygotsky, 1978), the creation and utilization of signs in an auxiliary manner is an attempt to solve psychological issues (to recall, compare, report, and select, among others) and is similar to the creation and use of tools in the psychology of the individual. Similarly, "the sign acts like psychological activity instrument that is akin to the role of tool used in labor" (p. 52). Vygotsky (1978) explained that

the human speech is the most far-reaching of the signal systems developed by human beings in light of effects and the most crucial moment in the intellectual development, 
which leads to the human forms of practical and abstract intelligence arises when speech and practical activity, two independent branches of development connects (p. 24).

As mentioned in the earlier sections, the ZPD is the core element in Vygotsky's theory and is defined as the distance between the level of real development (as displayed by independence problem solving) and the degree of potential development (as displayed via problem-solving under the directions of an adult or in cooperation with more capable peers) (p. 86). The ZPD refers to the amount of learning that a student is capable of doing under proper directions (Schunk, 2000). The ZPD facilitates different processes of development. What is significant for the ZPD concept in the context of learning is that it is developed through the child-individual interactions in the child's environment.

To sum up, ICT integration refers conceptually to the use of technology as a powerful tool to assist students in learning different content areas and analyzing and solving problems with the help of newly learned skills and knowledge in order to tackle real-life situations. ICT integration has been linked with the promotion of student learning via collaborative involvement in actual, challenging tasks that stem from different disciplines in the context of complex environments for the inquiry and activity of students. The constructivism approach to ICT integration has been deemed to provide distinct opportunities for a transformative method of education.

\section{Related Studies}

Several empirical studies are discussed in this section to clarify the researcher's understanding of previous related research and also to demonstrate where this study started from and to show the gaps in the existing body of research (Al-Shboul et al., 2017; Alkhawaldeh \& Menchaca, 2014; Rababah et al., 2012; Sahin-Kizil, 2011; Ullah et al., 2017)

To start with, Sahin- Kizil (2011) investigated the ICT usage and the attitudes of high school EFL teachers in Turkey towards ICT, where he focused on the relationship between computer attitudes and extension of ICT usage, computer attributes and personal characteristics. The findings found that EFL teachers hold positive attitudes towards the use of ICT for educational purposes. However, the responses indicate that insufficient class time and inadequate training opportunities are the major obstacles in the process of ICT integration.

Locally, Rababah, Bani-Melhem, Jdaitawi, Rababah \& Rababah. (2012) conducted a study in which they investigated the barriers that inhibit Jordanian EFL in-service teachers from using ICT in their instruction through the utilization of semi-structured interviews. The current study has revealed that the integration of ICT in EFL instruction is generally low among the EFL teachers due to a key of barriers that face them. These barriers include lack of time, lack of training, lack of support and resources, lack of confidence, lack of computer hardware and software, and lack of competence. Another local study carried out by Alkhawaldeh \& Menchaca (2014) where they explored barriers to utilizing information and communication technologies (ICT) by students, teachers, and administrators. A significant number of barriers were related to "facilitating conditions," a category that placed significant responsibility on the Ministry of Education to offer increased resources and opportunities to facilitate the 
process of integrating technology into education in Jordan. Additionally, Al-Shboul, Al-Saideh, \& Al-Labadi (2017) investigated the barriers that might prevent the effective use of ICT in higher education in Jordan from the learners' perspectives. The results of the analysis, however, revealed that most students have positive perceptions towards the use of ICT in the classroom instruction in institutions of higher education in Jordan.

Ullah, Khan, \& Aamirs's (2017) study aimed at exploring the relationship between undergraduate students' attitudes towards Technology Acceptance Model, with a special reference to online learning. The key findings of the study show no significant relationship between students' interest in computers, usefulness of computers to students and easiness in using online learning at the undergraduate level. Slow and meager internet facilities, with least understanding of students about online learning, often develop a negative approach among students regarding online learning.

Even though Jadara University has launched several initiatives and suggested the integration of ICT into instruction (Rababah, 2019) and despite seemingly countless studies addressing ICT barriers that students face, most of these studies are not in the English language context nor are they concerned with students ICT barriers. In other words, studies dedicated to students' ICT barriers in the English language settings are lacking in the region (Al-Shboul et al., 2013; Alkhawaldeh \& Menchaca, 2014; Rababah et al., 2012) and specifically in the Jordanian context.

\section{Methods}

To explore the barriers that students face and to get in-depth information about this phenomenon, this current study employed a qualitative approach. The researcher has made use of focus group interview which is a tool for qualitative research, where a group of people are selected and asked about their opinion or perceptions of a particular topic (Creswell, 2013). The population of the study included all English language students of Jadara University, where the purposive sample of the study included (12) students. The respondents were informed about the objectives of the study and were ensured that all data obtained from them will be only used for academic research. The participants were interviewed to answer several questions in order to find out the obstacles they face. To analyze the data, the researcher used coding to make sense out of text data, and to collapse these codes into broad themes.

\section{Results}

To achieve the aim of the study, this section presents the findings based on the tool used to answer the question entitled "What are the obstacles that English language students face while learning through eLearning platforms? Using the convenience sample, twelve students were interviewed using the focused group interview instrument. The twelve students provided their feedback concerning the constraining factors that they experienced while learning through ICT platforms. Their responses revealed three themes, namely, lack of effective training, lack of accessibility, and instructors' inconsistent teaching styles. The following paragraphs provide a qualitative analysis of students' responses. 


\section{The First Theme: Lack of Effective Training}

The students' responses revealed that they are not trained to use such platforms. The students highlighted this theme as one of the barriers that block their learning in ICT settings. Among twelve of the interviewed students, eight stated that they are not able to use these platforms, and some of their responses are provided in the following paragraphs.

To begin with, SA stated that "among the primary obstacles that I faced stems from my limited training skill I have experienced" (SA, Interview, March25, 2020). SD stated also that "the majority of students were inactive because they don't know how to get involved in this process, there were not enough training opportunities for students in the use of ICTs in a classroom environment”. (SD, Interview, March 25, 2020)

According to the study respondents, training is an important factor to keep one engaged. SF stated that "our university may adopt some initiatives to train the student effectively how to use these platforms which could help enhance and maximize their learning"(SF, Interview, March 25, 2020).

\section{The Second Theme: Inconsistent Teaching Styles of Instructors}

Instructors' inconsistent teaching styles are the second theme obtained from the students' interviews. Ten of the participants claimed that they are distracted because of the inconsistent teaching styles and methods adopted by instructors (e.g., SL, Interview, March 25, 2020). The student, SG, asserted that "one cannot learn to pronounce a word properly by only reading texts, although this may be the preferred style of some other learners" (SE, Interview, March 25, 2020). Similarly, SC reported that "most teachers cannot cope with individual differences among students because of the styles adopted, so it is not easy to maintain the interest that brings students to the course" (SC, March 25, 2020). It is evident from the above responses that students face problems with inconsistent teaching styles adopted by their instructors.

\section{Third Theme: Lack of Accessibility}

The students' responses revealed a lack of access to resources as the third theme. The students highlighted this theme as one of the barriers that obstruct their online learning. Ten of the twelve respondents stated that they have barriers of accessibility and their responses are provided in the following paragraphs. To begin with, $\mathrm{SH}$ affirmed that "lack of access to resources is another complex factor that discourages us as students from reaching out to these platforms" (SH, Interview, March 25, 2020). SJ claimed that "a student would have no access to ICT materials because most of these were shared with other members of the family" (SJ, Interview, March 25, 2020)

The students' barriers related to the accessibility of ICT are widespread and differ from place to place. SH added, "I sometimes have no access to the Internet and sometimes slow and poor Internet facilities which impede my progress” (SH, Interview, March 25, 2020). 
Some results mentioned above have come consistent with the results of previous studies (Al-Shboul et al., 2017; Albirini, 2006; Alkhawaldeh \& Menchaca, 2014; Rababah et al., 2012; Sahin-Kizil, 2011; Ullah et al., 2017)

\section{Conclusion and Recommendations}

This qualitative study aimed at investigating obstacles faced by English language learners while having to use e-learning at Jadara University in Jordan. To get in-depth information about this phenomenon, this current study employed a focus group interview as an instrument for qualitative research. Twelve students were selected using the convenience sample. The twelve students provided their feedback concerning the constraining factors that they experienced while learning through ICT platforms. Their responses revealed three themes, namely, lack of effective training, lack of accessibility, and instructors' inconsistent teaching styles. The results of the current study are unique because they contribute to the field of ICT integration in EFL settings. This qualitative study may assist policymakers and educators in their evaluation of ICT and EFL initiatives, educational programs, materials, curricula and teaching procedures. Some of the recommendations include conducting further research into the speech acts used by Jordanians on different social networking platforms. Although barriers were significant, the paper recommended additional institutional support for the online learning and increased technical and pedagogical training for students.

\section{References}

Al_Amri, A., \& Rababah, L. (2020). The Effect of Using YouTube on Developing Elementary Students Vocabulary. Education and Linguistics Research, 6(1), 129-139.

Albirini, A. (2006). Cultural perceptions: The missing element in the implementation of ICT in developing countries. International Journal of Education and Development Using ICT, 2(1), 49-65.

Alkhawaldeh, N., \& Menchaca, M. (2014). Barriers to utilizing ICT in education in Jordan. International Journal on E-Learning, 13(2), 127-155.

Almwajeh, M., \& Rababah, L. (2018). Literature is the best tool of awaking moral understanding and evaluation: Wendell Berry's The Long-Legged House. AWEJ for Translation \& Literary Studies, 2(2), 69-80. https://doi.org/10.24093/awejtls/vol2no2.5

Almwajeh, M., \& Rababah, L. (2019). There is more to it than meets the eye: an intercultural study of religious speech acts between Jordanian and American students. International Journal of Linguistics, 11(1), 34-45. https://doi.org/10.5296/ijl.v11i1.14261

Al-Shboul, M., Al-Saideh, M., \& Al-Labadi, N. (2017). Learners' perspectives of using ICT in higher education institutions in Jordan. Instructional Technology, 14(3), 27-86.

Al-Shboul, M., Rababah, O., Al-Saideh, M., Betawi, I., \& Jabbar, S. (2013). A vision to improve e-Learning at the University of Jordan. World Applied Sciences Journal, 21(6), 902-914. https://doi.org/10.5829/idosi.wasj.2013.21.6.227

Banikalef, A., \& Rababah, L. (2018). Gender differences and emotional expressiveness on 


\section{Al Macrothink}

International Journal of Linguistics

ISSN 1948-5425

2020, Vol. 12, No. 3

Facebook: An analysis of prosodic features among Jordanian Facebookers. Studies in Linguistics and Literature, 2(3), 180-184. https://doi.org/10.22158/sll.v2n3p180

Creswell, J. W. (2013). Research design: Qualitative, quantitative, and mixed methods approaches. Sage publications.

Jdaitawi, M., Ishak, N., Taamneh, M., Gharaibeh, M., \& Rababah, L. (2011). The Effectiveness of Emotional Intelligence Training Program on Social and Academic Adjustment among First Year University Students. International Journal of Business and Social Science, 2(24), 251-258. https://doi.org/10.5539/ijps.v3n2p135

Rababah, I., \& Rababah, L. (2017). Investigating Arabic to Speakers of Other Languages (ASOL) Lecturers' Attitudes towards Utilizing Flipped Classroom Instruction (FCI): A Qualitative Study at Jordanian Public Universities. International Educational Studies, 10(7), 80-91. https://doi.org/10.5539/ies.v10n7p94

Rababah, I., \& Rababah, L. (2018). The actual use of brainstorming strategy among teachers of Arabic for speakers of other languages in writing classes. International Journal of English Linguistics, 9(1), 133-143. https://doi.org/10.5539/ijel.v9n1p15

Rababah, I., \& Rababah, L. (2018). The Level of Creative Writing among Non-Native Arabic Language Learners: A Quantitative Study at the University of Jordan Language Center. Manara Journal, 24(2), 79-95.

Rababah, L. (2018). An adapted version of Torrance Test of Creative Thinking (TTCT) in EFL/ESL writing: A rubric scoring and a review of studies. International Journal of English and Education (IJEE), 7(2), 128-136.

Rababah, L. (2019). Teachers' Integration of Information and Communication Technology (ICT) Tools into Writing Classes: A qualitative study. Journal of Education in Black Sea Region, 5(1), 30-36.

Rababah, L. (2019). Using Collaborative Learning Strategies to Improve Creativity in EFL Writing: Attitudes and Actual Use. Journal of Education in Black Sea Region, 5(1), 36-52. https://doi.org/10.5296/elr.v5i1.14507

Rababah, L., \& Almwajeh, M. (2018). Promoting Creativity in EFL/ESL writing through scaffolding strategy. International Journal of English and Education (IJEE), 7(3), 148-160.

Rababah, L., \& Bani Melhem, N. (2015). Investigation into Strategies of Creativity in EFL Writing in Jordan. Journal of Literature, Languages and Linguistics, 5(23), 14-25. Retrieved from http://www.iiste.org/Journals/index.php/JLLL/article/view/17777/18153

Rababah, L., \& Banikalef, A. A. (2019). The use of valuing strategies into enhancing creativity in EFL writing. Education and Linguistics Research, 5(1), 30-36. https://doi.org/10.5296/elr.v5i1.14507

Rababah, L., Alshehab, M., \& Bani Melhem, N. (2018). Exploring the Factors that Hinder Jordanian Students in Developing Creativity in EFL Writing. International Journal of 


\section{Macrothink}

International Journal of Linguistics

ISSN $1948-5425$ 2020, Vol. 12, No. 3

English and Education (IJEE), 7(3), 161-170.

Rababah, L., Bani-Melhem, N., Jdaitawi, M., Rababah, B., \& Rababah, O. (2012). EFL teachers' barriers to the use of ICT in instruction in Jordan. Proceedings of the 1st International Conference on Behavioural and Social Science Research (ICBSSR), 1-5.

Rababah, L., Halim, A., Jdaitawi, M., \& Bani Melhem, N. (2013). The level of creativity in English writing among Jordanian secondary school students. Arts and Design Studies, 10, 25-29. Retrieved from www.iiste.org/Journals/index.php/ADS/article/download/6094/6226

Rababah, L. (2020). Speech act analysis of WhatsApp statuses used By Jordanians. Review of European Studies, 12(2), 28-32.

Sahin-Kizil, A. (2011). EFL Teachers' Attitudestowards Information and Communication Technologies. 5th Internnatioonal Computer \& Instructional Technologies Symposium. Elazig, Turkey, 8, 120-130.

Ullah, O., Khan, W., \& Khan, A. (2017). Students' Attitude towards Online Learning at Tertiary Level. PUTAJ--Humanities and Social Sciences, 25(1-2).

\section{Copyrights}

Copyright for this article is retained by the author(s), with first publication rights granted to the journal.

This is an open-access article distributed under the terms and conditions of the Creative Commons Attribution license (http://creativecommons.org/licenses/by/4.0/) 